\title{
Bacterial diversity and community structure in the sediment of the middle and lower reaches of the Yellow River, the largest turbid river in the world
}

\author{
Na Xia, Xinghui Xia*, Baotong Zhu, Shaokui Zheng, Jing Zhuang \\ School of Environment, Beijing Normal University, Beijing 100875, PR China
}

\begin{abstract}
The characteristics of bacterial community in the sediment of the middle and lower reaches of the Yellow River, the largest turbid river in the world, were studied by using the 16S rRNA gene clone library technique. Sediment cores with $25 \mathrm{~cm}$ depth were collected from 5 sites along the river and each sediment core was sliced into 5 layers for phylogenetic analyses. For the 25 clone libraries, a total of 2496 16S rRNA gene sequences were obtained and selected for taxonomic analysis. Furthermore, 1353 distinct operational taxonomic units (at the $97 \%$ identity level) were assigned, suggesting that a large number of bacterial taxa existed in the sediments of the Yellow River. The dominant bacterial groups in each sediment sample were affiliated with the subphyla Betaproteobacteria (mainly order Burkholderiales) and Gammaproteobacteria (mainly order Xanthomonadales), followed by Bacteroidetes, Acidobacteria, and Verrucomicrobia. Based on Shannon index values, bacterial diversity in Yellow River sediment was higher than that in other, less turbid rivers. Bacterial community compositions differed among the 5 sampling sites, due to differences in environmental variables. Redundancy analysis and Monte Carlo permutation test results demonstrated the significant effects of ammonium nitrogen and nitrate nitrogen concentrations on bacterial community structures $(p<0.05)$. Due to the high sediment concentration and high-frequency resuspension and deposition of sediment in the Yellow River, the bacterial community exhibited vertical variations but did not show a significant trend with depth in the sediment core samples.
\end{abstract}

KEY WORDS: Bacterial community $\cdot$ Spatial and vertical variation $\cdot$ Sediment $\cdot$ High sediment concentration · Yellow River

\section{INTRODUCTION}

Microorganisms play an important role in the transformation of complex organic matter and the biogeochemical cycles of many elements, including nitrogen, carbon, and sulfur (Nealson 1997, Junier et al. 2007, Kondo \& Butani 2007, Xia et al. 2009). Researchers investigate bacterial community compositions in order to understand global patterns of bacterial diversities as well as local and global biogeochemical processes (Zehr \& Ward 2002, Vieira et al. 2008). Microbial communities in buried sediments may rep- resent up to one-third of the earth's micro-biomass (Whitman et al. 1998). A global survey of bacterial communities in natural environments found that sediment communities may be more phylogenetically diverse than those from other environments, including soils (Lozupone \& Knight 2007). Environmental factors, such as salinity (Edlund et al. 2006), organic matter (D'Hondt et al. 2004), and nutrients (Nelson et al. 2007), can influence the microbial community structure in sediment environments. D'Hondt et al. (2004) revealed that high levels of organic matter in sediments greatly stimulate prokaryotic activity and 
result in highly diverse prokaryotic populations. Therefore, it is essential to understand the compositions of microbial communities in sediments under different environment conditions.

River ecosystems are important freshwater habitats for microorganisms. Studies have focused on the horizontal distribution of microbial communities in river surface sediments; results indicate that Proteobacteria, Chloroflexi, Actinobacteria, Bacteroidetes, and Planctomycetes are the most common phyla in freshwater sediment environments (Tamaki et al. 2005, Wilms et al. 2006, Nelson et al. 2007). Studies have further suggested that, due to the variability of sediment environmental conditions, bacterial communities in river sediments differ in abundance, physiological activity, and phylotype diversity (Nealson 1997, Lozupone \& Knight 2007, Nelson et al. 2007).

In turbid rivers with a high concentration of suspended sediments, the deposition of suspended sediment and resuspension of deposited sediments may affect the microbial communities in sediments. The spatial and vertical distributions of microorganism in turbid rivers may differ from those in other rivers. However, few studies have been conducted on bacterial diversities and community structures in turbid rivers sediments with high concentrations of suspended sediment.

The Yellow River in China, with an average suspended sediment concentration of $22 \mathrm{~g} \mathrm{l}^{-1}$ (YRCC 2010), is the largest turbid river in the world. Espe-

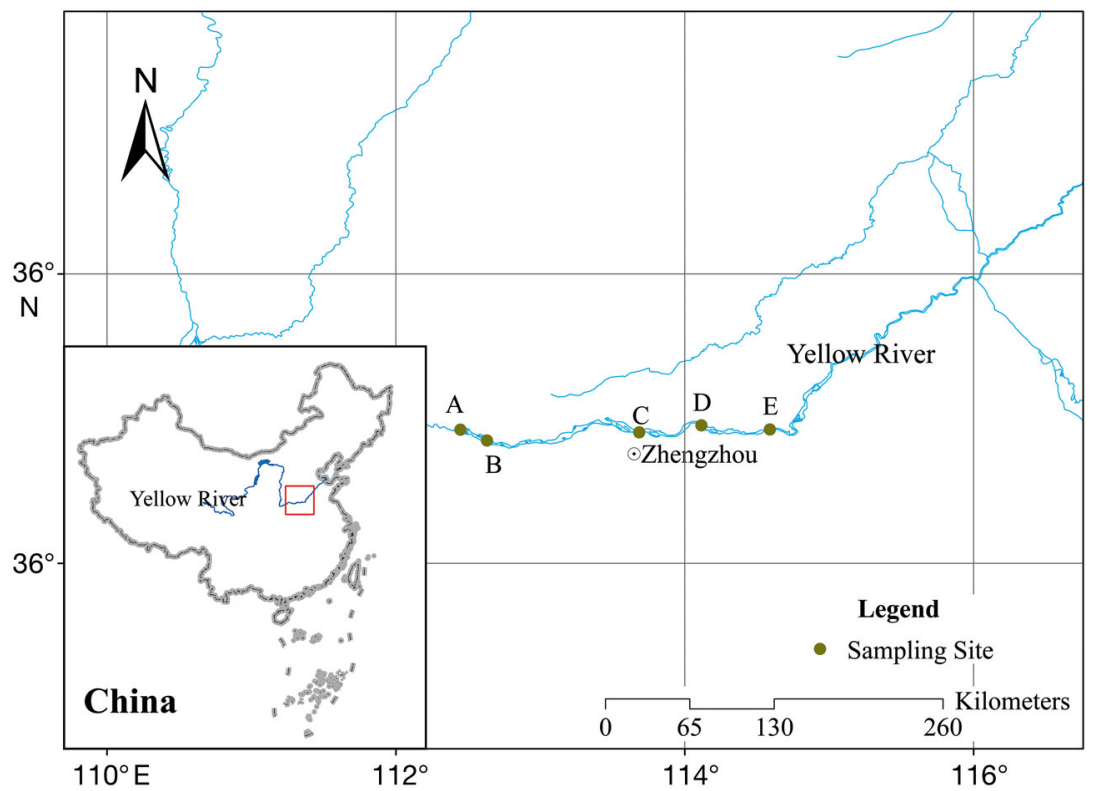

Fig. 1. Location of 5 sediment core sampling sites on the Yellow River, China. A: Xiaolangdi Reservior Dam; B: Mengjin Bridge; C: Huayuankou Bridge; D: Sanguan Temple; E: Kaifeng Bridge cially in the middle and lower reaches of the river, hydrodynamic conditions vary greatly due to watersediment regulation in the Xiaolangdi Reservoir, which results in high-frequency resuspension and deposition of sediment (Yang et al. 2008).

In the present study, we selected the Yellow River as a typical river to study the patterns of bacterial community structure and diversity at various depths in the sediment of turbid rivers. Samples were collected from 5 sites in the middle and lower reaches of the Yellow River. The spatial variation of bacterial community structures in the sediments was examined. The variations of environmental parameters and bacterial 16S rRNA gene clone libraries in sediments with vertical depth were also investigated. In addition, the relationships between environmental variables and bacterial community structures in the sediments were analyzed.

\section{MATERIALS AND METHODS}

\section{Site description and sample collection}

The Yellow River, the second largest river in China, is famous for having the highest sediment concentration in the world (Liu et al. 2013). Sediment cores were collected from 5 sites in the middle and lower reaches of the Yellow River (Fig. 1). These sites were selected based on the river's characteristics, and located at 5 important hydrological stations, namely Xiaolangdi Reservior Dam (345' $\left.18.5^{\prime \prime} \mathrm{N}, 112^{\circ} 26^{\prime} 46.5^{\prime \prime} \mathrm{E}\right)$,

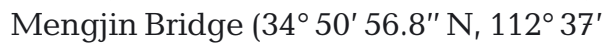
45.7"E), Huayuankou Bridge (345 $54^{\prime}$ $\left.16.8^{\prime \prime} \mathrm{N}, 114^{\circ} 35^{\prime} 22.1^{\prime \prime} \mathrm{E}\right)$, Sanguan Temple (34 $\left.56^{\prime} 59.2^{\prime \prime} \mathrm{N}, 114^{\circ} 07^{\prime} 00.8^{\prime \prime} \mathrm{E}\right)$, and Kaifeng Bridge (345' $25.1^{\prime \prime} \mathrm{N}, 114^{\circ} 35^{\prime}$ $\left.22.1^{\prime \prime} \mathrm{E}\right)$, which are representative of the middle and lower reaches of the Yellow River. The five sites were assigned the letters A, B, C, D, and E, respectively.

For each sampling site, triplicate sediment cores of $25 \mathrm{~cm}$ depth were randomly collected using a corer sampler in an area of $2 \mathrm{~m}^{2}$, which was approximately $2 \mathrm{~m}$ away from the water edge. Each sediment core was cut in situ into 5 slices at the following depths: 0-5, 5-10, 10-15, 15-20, and 20-25 cm; these were assigned numbers 1, 2, 3, 4 and 5, respectively. Each sediment 
layer sample was labeled by combining the letter representing the sampling site and the number representing the sediment layer. For example, labels A1, A2, A3, A4, and A5 represented the samples at the depths of $0-5,5-10,10-15,15-20$, and $20-25 \mathrm{~cm}$, respectively, from site $A$. For each sampling site, triplicate core samples from the same sediment layer were mixed and transferred to sterilized polypropylene tubes. All the sediment samples were stored frozen and quickly transported back to the laboratory for experimental analysis. Lab experiments began within $48 \mathrm{~h}$ after sampling.

\section{Measurements of physical and chemical parameters}

For each sediment sample, pH and oxidation-reduction potential (ORP) were simultaneously measured in situ. A total of $10 \mathrm{~g}$ of sediment was placed into $10 \mathrm{ml}$ of distilled deionized water, vortexed, allowed to stand for $30 \mathrm{~min}$, and analyzed using a standardized $\mathrm{pH}$ probe (Mettler). Other parameter analyses were performed in the laboratory. To determine the water content, we weighed each fresh sediment sample before and after the samples were dried at $60^{\circ} \mathrm{C}$ for $24 \mathrm{~h}$. The values were calculated as follows: [(weight of fresh sediment) - (weight of dried sediment)] / (weight of fresh sediment). Ammonium nitrogen $\left(\mathrm{NH}_{4}-\mathrm{N}\right)$, nitrate nitrogen $\left(\mathrm{NO}_{3}-\mathrm{N}\right)$, and nitrite nitrogen $\left(\mathrm{NO}_{2}-\mathrm{N}\right)$ for each fresh sediment sample were colorimetrically measured with an Autoanalyser 3 (Liu et al. 2013). For the determination of total nitrogen (TN) and total organic carbon (TOC), each sediment sample was freeze-dried and sieved through a 60-mesh stainless screen. TN and TOC were then analyzed using a Carlo CHN elemental analyzer (Vario E1, Elementar Analysensyteme) as described in Liu et al. (2011).

\section{DNA extraction, PCR amplification and 16S rRNA clone library construction}

Total genomic DNAs were extracted from fresh sediments by using the UltraClean Soil DNA Isolation Kit (MO BIO). DNA was eluted with $50 \mu \mathrm{l}$ of ultra-sterile pure water and stored at $-20^{\circ} \mathrm{C}$. The extracted DNA was used for the clone library construction analysis. Approximately $20 \mathrm{ng}$ of DNA from each sediment sample was amplified for the $16 \mathrm{~S}$ rRNA gene by PCR (applying a predenaturation step of $5 \mathrm{~min}$ at $95^{\circ} \mathrm{C}$, followed by 30 cycles of $1 \mathrm{~min}$ at $94^{\circ} \mathrm{C}$, 30 s at $53^{\circ} \mathrm{C}$ and 2 min at $72^{\circ} \mathrm{C}$, and a final elongation step of $72^{\circ} \mathrm{C}$ for $\left.15 \mathrm{~min}\right)$, using the universal forward primer 27F (5'-AGA GTT TGA TCM TGG CTC AG-3') and the reverse primer 1492R (5'-TAC GGY TAC CTT GTT ACG ACT T-3') (Lane 1991). PCR products were visualized by staining with ethidium bromide following agarose gel electrophoresis (Thermo-Scientific). The images were recorded using a Chemi-Smart 3000 gel documentation system (Vilber Lourmat). PCR products were purified using a DNA Fragment Purification Kit Ver.2.0 (TaKaRa) and subsequently cloned into a pMD19-T vector system (TaKaRa) and transformed into Escherichia coli Top 10. At the transformation step, the chosen cells were incubated with the ligation mix for $35 \mathrm{~min}$, and then heat shocked at $42^{\circ} \mathrm{C}$ for $45 \mathrm{~s}$. Individual clones, assumed to harbor the expected inserts, were grown at $37^{\circ} \mathrm{C}$ for $8 \mathrm{~h}$ in Luria Broth supplemented with ampicillin. A total of 2496 recombinant clones were singly picked from the 25 clone libraries, and 16S rRNA gene sequences were determined by the MO BIO Company. Nucleotide sequencing reactions were performed with the vector primer 519F (5'-CAG CAG CCG CGG TAA TAC-3').

\section{Sequence, phylogenetic, diversity and statistical analysis}

Among the assembled sequences, those with low quality were discarded; chimeric artifacts were examined using Mothur program (Schloss et al. 2009) and then removed. The Ribosomal Database Project (RDP) classifier was used to assign 16S rRNA gene sequences (Wang et al. 2007). The representative sequences of the dominant genera (comprising $>0.5 \%$ of the 2496 sequences) were selected and aligned. The phylogenetic tree was constructed by the neighbor-joining method (with 1000 bootstrap replicates) using MEGA v5.0. This constructed tree was then related to the taxonomic assignment of the dominant genera among the 25 bacterial clone libraries. The sequences of the dominant genera were deposited into the GenBank database under the accession numbers: KF300927 to KF300956.

In this study, 16S rRNA gene sequences with $>97 \%$ similarities were assigned to the same operational taxonomic unit (OTU) by using the Mothur program (Schloss et al. 2009). The diversity of OTUs was further examined by rarefaction analysis. Richness and diversity statistics were also calculated using the Mothur program, including Shannon index, ACE, Chao1, and evenness (Schloss et al. 2009). These 
indices are useful statistical tools that compare the relative complexity of communities and estimate the completeness of sampling.

The relationships between environmental variables and bacterial community compositions were studied. Detrended correspondence analysis (DCA) was performed to determine whether or not unimodal or linear methods were appropriate. The longest gradient resulting from DCA was $<2$. This result suggested that the operation parameters exhibited a linear, rather than a unimodal response to bacterial communities (Jongman et al. 1995). We performed redundancy analysis (RDA) to compare species-environment correlations. In this study, the representative sequences of the dominant phyla and subphyla (comprising $>1.0 \%$ of 2496 sequences) were used to analyze the correlation with environmental variables by RDA. The Monte Carlo permutation test (499 permutations) with unrestricted permutation was performed to investigate the statistical significance (at the $5 \%$ level) of relationships between taxa data and environmental variables (Salles et al. 2004). Multivariate statistics were performed using CANOCO 4.5 software. One-way analysis of variance was performed to distinguish the differences in each environmental parameter among the 5 sampling sites using the software of SPSS v20.0. The significance level was set at $\mathrm{p}<0.05$.

\section{RESULTS AND DISCUSSION}

\section{Environmental parameters}

As shown in Fig. 2 \& Table S1 in the Supplement at www.int-res.com/articles/suppl/a071p043_supp .pdf, the environmental properties of the 5 sampling sites varied widely. The water content of all the sediment samples ranged from 11.3 to $32.1 \%$, which was lower than that of other rivers (GarciaRuiz et al. 1998, Doong \& Lin 2004). This is probably due to the large particle size of the Yellow River sediment (Liu et al. 2013). ORP and $\mathrm{pH}$ of the sediment samples ranged from -31 to $-50 \mathrm{mV}$, and from 7.69 to 8.10 , respectively. TOC varied between 0.028 and $0.194 \%$, and TN concentration ranged from 9.0 to $1139.8 \mathrm{mg} \mathrm{kg}^{-1}$. The concentrations of $\mathrm{NH}_{4}-\mathrm{N}, \mathrm{NO}_{3}-\mathrm{N}$, and $\mathrm{NO}_{2}-\mathrm{N}$ ranged from 0.1 to 19.7, 0.1 to 92.2 and 0.01 to $0.26 \mathrm{mg} \mathrm{kg}^{-1}$, respectively. For each environmental parameter, there were significant differences among the 5 sampling sites $(p<0.05)$ (Table $\mathrm{S} 1)$. For each sediment sample, negative correlations were observed between
$\mathrm{pH}$ and ORP $(\mathrm{p}<0.01)$, water content $(\mathrm{p}<0.05)$ and $\mathrm{NH}_{4}-\mathrm{N}(\mathrm{p}<0.05)$. Positive correlations were observed between ORP and both water content $(\mathrm{p}<0.05)$ and $\mathrm{NH}_{4}-\mathrm{N}(\mathrm{p}<0.05)$, between $\mathrm{NH}_{4}-\mathrm{N}$ and $\mathrm{NO}_{3}-\mathrm{N}(\mathrm{p}<0.05)$ and between $\mathrm{TN}$ and $\mathrm{NO}_{2}-\mathrm{N}$ concentration $(p<0.01)$ (Table S2).

\section{OTU clustering and diversity of bacterial community}

Twenty-five clone libraries were constructed to elucidate the patterns of the bacterial community structures and diversities for the 5 sediment cores. A total of 2496 16S rRNA gene sequences for all clone libraries were obtained and selected for taxonomic analysis. The number of clones of each clone library ranged from 65 to 135, with an average of 100 (Table 1). Based on a taxa cutoff set at $97 \%$ similarity, the number of distinct OTUs of each clone library ranged from 25 to 112, with an average of 71 (Table 1). When all clone libraries were assembled together, the number of distinct OTUs was 1353. This finding suggested that a large number of bacterial taxa existed in the Yellow River sediments. As shown in Table 1, the Good's coverage for the sedimentary clone libraries ranged from 7 to $88 \%$, with an average of $40 \%$. As shown in Fig. 3, rarefaction curves carried out for all the clone libraries showed that most of the curves did not reach saturation, indicating that the bacterial diversities in the Yellow River sediment were probably higher than those found in the sediment samples of this study.

To analyze the diversities and richness of the bacterial communities in the present sediment samples, the Shannon index, ACE, Chao1, and evenness of each clone library were calculated (Table 1 ). The values of the Shannon index ranged from 2.17 to 4.56 , with an average of 3.92. The values of ACE and Chao1 ranged from 40.4 to 5204.5 and from 40 to 3490, respectively. The evenness of OTU frequencies in each gene clone library ranged from 0.804 to 0.996, except for clone library B1 with an evenness value of 0.674

According to the results shown in Table 2, the bacterial diversity in the sediment of the Yellow River was higher than in other, less turbid rivers and lakes around the world. This might be because the high concentration of suspended sediment in the Yellow River provides more interface for bacterial growth than other rivers and lakes; previous studies demonstrated that the abundance of nitrifying and denitrifying bacteria as well as polycyclic aromatic hydrocar- 


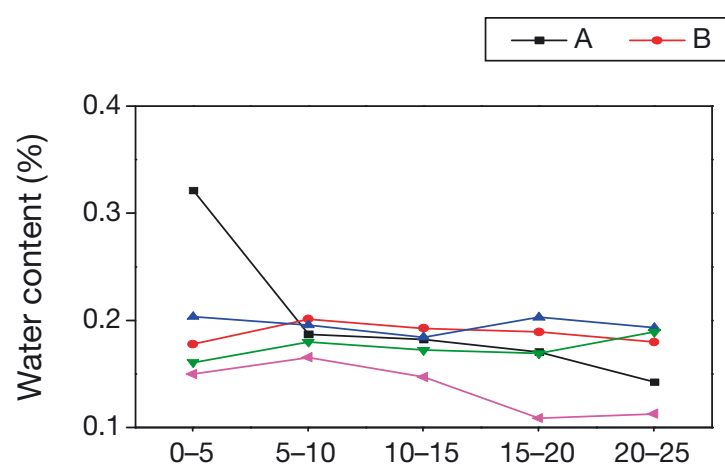

$\multimap \mathrm{C} \rightarrow \mathrm{D} \leftarrow \mathrm{E}$
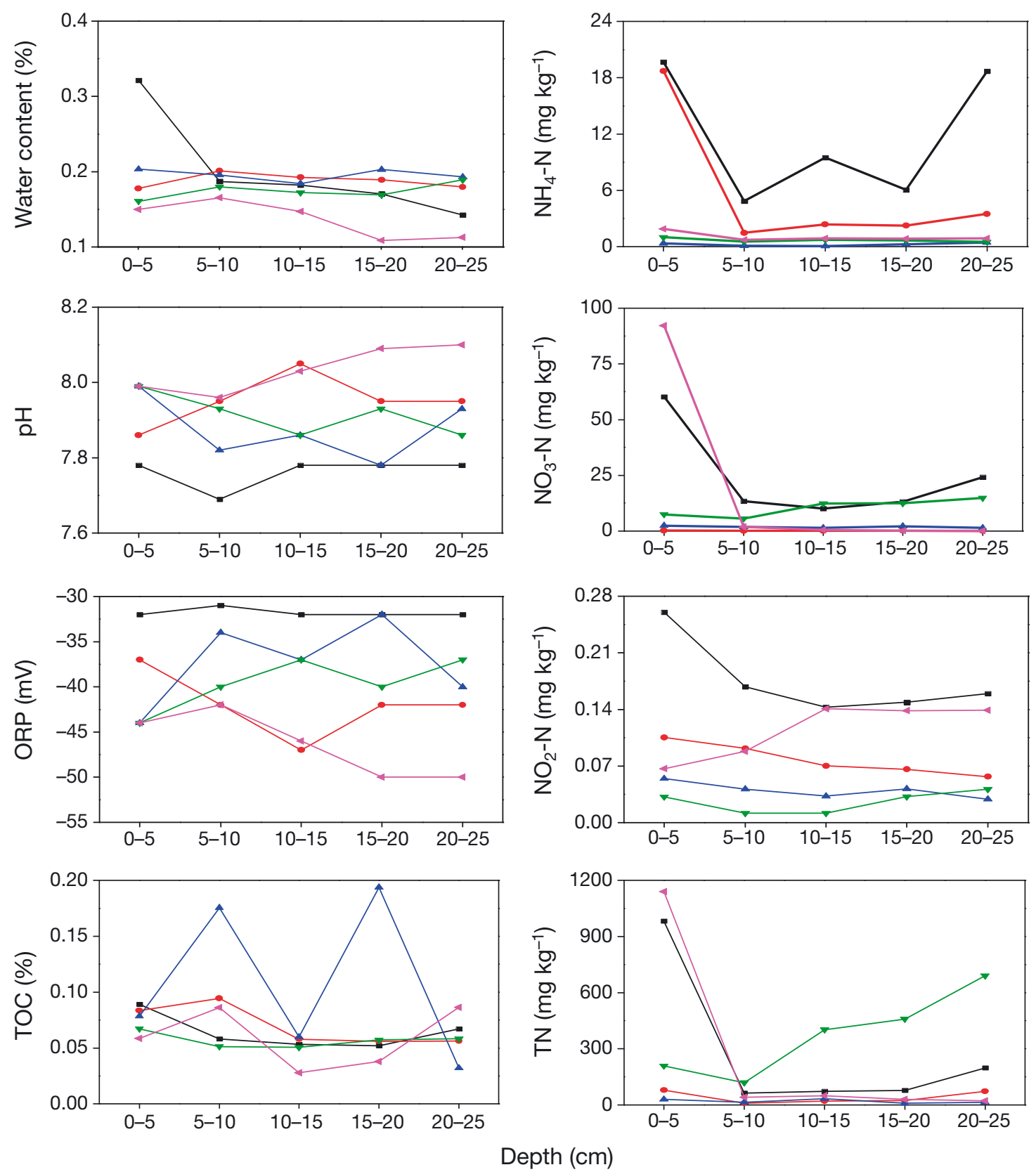

Fig. 2. Depth profiles of environmental parameters in sediment cores taken from 5 sites (A to E) on the Yellow River (see Fig. 1 for site locations). Five cores were taken at the depths indicated at each site. ORP: oxidation-reduction potential; TOC: total organic carbon; TN: total nitrogen; $\mathrm{NH}_{4}-\mathrm{N}$ : ammonium nitrogen; $\mathrm{NO}_{2}-\mathrm{N}$ : nitrite nitrogen; $\mathrm{NO}_{3}-\mathrm{N}$ : nitrate nitrogen

bon biodegrading bacteria increases with suspended sediment concentration (Xia et al. 2006, 2009, Liu et al. 2013). In addition, the resuspension and deposition of sediment might provide more habitat types for both aerobic and anaerobic bacterial growth, leading to the higher bacterial diversity in the Yellow River sediment than in other less turbid rivers.

\section{Phylogenetic analysis}

The RDP classifier was used to assign the $249616 \mathrm{~S}$ rRNA gene sequences. A phylogenetic tree was constructed to show the relationships of the taxonomic assignment of the dominant genera among the 25 bacterial clone libraries. The assigned results showed 
Table 1. Bacterial diversity indices of the 25 sediment samples taken from 5 sites (A to E) on the Yellow River (see Fig. 1). Five cores were taken at each site; samples taken at depths $0-5,5-10,10-15,15-20$, and $20-25 \mathrm{~cm}$ were

numbered 1, 2, 3, 4 and 5, respectively. OTU: operational taxonomic unit

\begin{tabular}{|lccccccc|}
\hline Sample & $\begin{array}{c}\text { No. of } \\
\text { clones }\end{array}$ & $\begin{array}{c}\text { No. of } \\
\text { OTUs }\end{array}$ & $\begin{array}{c}\text { Cover- } \\
\text { age }\end{array}$ & $\begin{array}{c}\text { Shan- } \\
\text { non }\end{array}$ & Chao1 & ACE & $\begin{array}{c}\text { Even- } \\
\text { ness }\end{array}$ \\
\hline A1 & 96 & 67 & 48 & 4.06 & 178.4 & 189.1 & 0.965 \\
A2 & 105 & 80 & 36 & 4.22 & 325.7 & 842.8 & 0.963 \\
A3 & 100 & 87 & 17 & 4.35 & 3490.0 & 4880.0 & 0.974 \\
A4 & 135 & 112 & 24 & 4.56 & 987.5 & 5204.5 & 0.966 \\
A5 & 117 & 71 & 58 & 4.01 & 155.0 & 168.5 & 0.940 \\
B1 & 78 & 25 & 81 & 2.17 & 40.0 & 46.6 & 0.674 \\
B2 & 98 & 65 & 40 & 3.65 & 492.8 & 2926.7 & 0.873 \\
B3 & 113 & 60 & 57 & 3.29 & 190.7 & 688.7 & 0.804 \\
B4 & 103 & 68 & 40 & 3.75 & 540.8 & 4905.2 & 0.888 \\
B5 & 99 & 25 & 88 & 2.62 & 41.5 & 40.4 & 0.812 \\
C1 & 65 & 56 & 26 & 3.97 & 197.0 & 219.5 & 0.987 \\
C2 & 99 & 73 & 36 & 4.07 & 398.5 & 1425.6 & 0.948 \\
C3 & 100 & 67 & 42 & 3.88 & 480.3 & 1238.6 & 0.922 \\
C4 & 100 & 87 & 23 & 4.41 & 452.8 & 452.8 & 0.987 \\
C5 & 100 & 62 & 54 & 3.89 & 91.4 & 312.4 & 0.943 \\
D1 & 100 & 69 & 39 & 3.87 & 526.5 & 1254.7 & 0.913 \\
D2 & 100 & 76 & 35 & 4.15 & 373.1 & 1056.0 & 0.959 \\
D3 & 100 & 91 & 16 & 4.47 & 62.0 & 707.3 & 0.991 \\
D4 & 100 & 71 & 38 & 3.99 & 449.2 & 1852.0 & 0.936 \\
D5 & 100 & 96 & 7 & 4.54 & 1522.0 & 1883.3 & 0.996 \\
E1 & 100 & 81 & 30 & 4.28 & 426.0 & 747.0 & 0.975 \\
E2 & 95 & 70 & 39 & 4.08 & 306.1 & 540.8 & 0.962 \\
E3 & 100 & 68 & 43 & 3.91 & 296.0 & 786.5 & 0.926 \\
E4 & 98 & 64 & 43 & 3.64 & 372.0 & 703.9 & 0.876 \\
E5 & 95 & 77 & 29 & 4.21 & 353.4 & 1243.1 & 0.969 \\
\hline
\end{tabular}

that $98.4 \%$ of these sequences could be classified and belonged to 21 phyla, including Proteobacteria, Bacteroidetes, Acidobacteria, Planctomycetes, Verrucomicrobia, Actinobacteria, Firmicutes, Gemmatimonadetes, Chlorobi, Chloroflexi, Cyanobacteria, Deferribacteres, Fusobacteria, Lentisphaerae, Nitrospira, Spirochaetes, BRC1, OD1, OP10, TM7, and WS3 (Fig. 4). The remaining sequences $(1.6 \%)$, which could be novel phylotypes, were classified into unclassified Bacteria. This result suggested that considerable diverse bacteria existed in the Yellow River sediment.

The most abundant sequences in the Yellow River sediment corresponded to Proteobacteria (1958 sequences, $78.5 \%$ ), which were widely distributed in all the sediment samples (Fig. 4). The remaining sequences were mainly related to Bacteroidetes (223 sequences, $8.9 \%$ ), Acidobacteria (156, $6.3 \%), \quad$ Planctomycetes (26, $1.0 \%)$, Actinobacteria (13, 0.5\%), and Cyanobacteria (13, 0.5\%). Many studies suggested that clones belonging to Proteobacteria, Bacteroidetes, and Acidobacteria are the dominant groups in
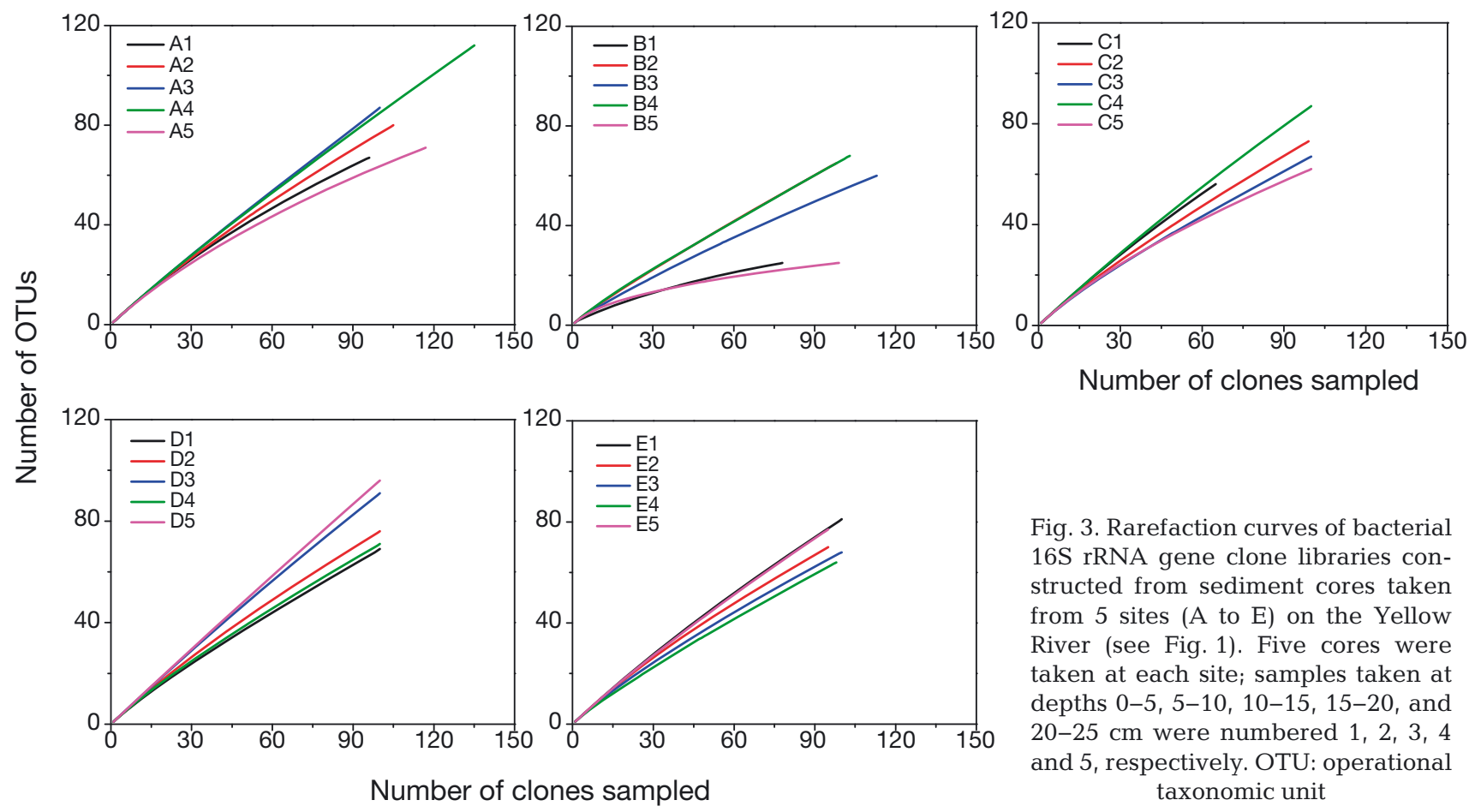

Fig. 3. Rarefaction curves of bacterial 16S rRNA gene clone libraries constructed from sediment cores taken from 5 sites (A to E) on the Yellow River (see Fig. 1). Five cores were taken at each site; samples taken at depths $0-5,5-10,10-15,15-20$, and 20-25 cm were numbered $1,2,3,4$ and 5, respectively. OTU: operational taxonomic unit 
Table 2. The bacterial diversity of sediment samples from different rivers and lakes worldwide. Shannon index values shown are the range and mean \pm SD (except for data from Marxsen et al. 2010, where $n=1$ ). DGCE: Denaturing Gradient Gel Electrophoresis; TGGE: Temperature Gradient Gel

\begin{tabular}{|c|c|c|c|c|}
\hline Source location & $\begin{array}{l}\text { Sediment } \\
\text { depth }(\mathrm{cm})\end{array}$ & $\begin{array}{c}\text { Biological } \\
\text { analysis method }\end{array}$ & $\begin{array}{l}\text { Shannon } \\
\text { index }\end{array}$ & References \\
\hline Yellow River, China & $0-5$ & Clone library & $\begin{array}{c}2.17-4.28 \\
3.92 \pm 0.55\end{array}$ & This study \\
\hline Yellow River, China & $0-25$ & Clone library & $\begin{array}{c}4.13-5.5 \\
4.91 \pm 0.74\end{array}$ & This study \\
\hline Yangtze River, China & $0-5$ & BIOLOG & $\begin{array}{c}2.41-4.20 \\
3.18 \pm 0.75\end{array}$ & Wang et al. (2010) \\
\hline Songhua River, China & Surface & DGGE & $\begin{array}{c}2.10-2.66 \\
2.34 \pm 0.25\end{array}$ & Li et al. (2008) \\
\hline Anacostia River, USA & Surface & DGGE & $\begin{array}{c}2.1-2.4 \\
2.32 \pm 0.25\end{array}$ & Bushaw-Newton et al. (2012) \\
\hline Mulargia River, Italy & $0-1.5$ & TGGE & 2.98 & Marxsen et al. (2010) \\
\hline Breitenbach River, Germany & $0-1.5$ & TGGE & 3.23 & Marxsen et al. (2010) \\
\hline Ebro River, Spain & $0-5$ & DGGE & $\begin{array}{c}1.02-1.17 \\
1.11 \pm 0.05\end{array}$ & Van Der Zaan et al. (2010) \\
\hline Onyx River, Antarctic continent & $0-10$ & Clone library & $\begin{array}{c}3.78-3.90 \\
3.84 \pm 0.04\end{array}$ & Zeglin et al. (2011) \\
\hline Dongping Lake, China & $0-15$ & Clone library & $\begin{array}{c}1.47-2.36 \\
2.02 \pm 0.24\end{array}$ & Song et al. (2012) \\
\hline
\end{tabular}

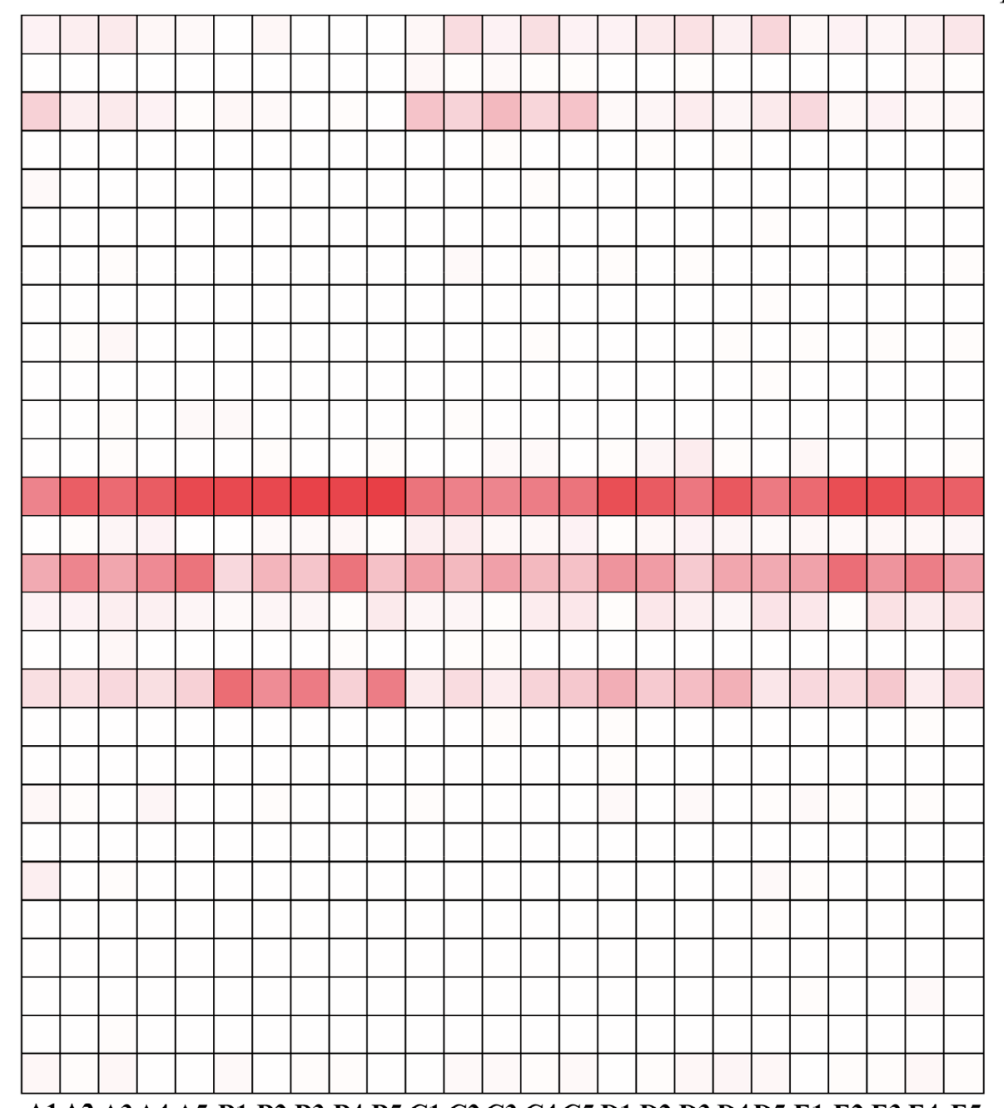

A1 A2 A3 A4 A5 B1 B2 B3 B4 B5 C1 C2 C3 C4 C5 D1 D2 D3 D4 D5 E1 E2 E3 E4 E5

\section{Phylum}

\begin{tabular}{|c|c|}
\hline Acidobacteria & $6.25 \%$ \\
\hline Actinobacteria & $0.52 \%$ \\
\hline Bacteroidetes & $8.93 \%$ \\
\hline Chlorobi & $0.12 \%$ \\
\hline Chloroflexi & $0.16 \%$ \\
\hline Deferribacteres & $0.04 \%$ \\
\hline Firmicutes & $0.28 \%$ \\
\hline Fusobacteria & $0.04 \%$ \\
\hline $\begin{array}{l}\text { Gemmatimonadetes } \\
\text { Lentisphaerae }\end{array}$ & $\begin{array}{l}0.44 \% \\
0.04 \%\end{array}$ \\
\hline Nitrospira & $0.32 \%$ \\
\hline Planctomycetes & $1.04 \%$ \\
\hline Proteobacteria & $78.45 \%$ \\
\hline Alphaproteobacteria & $3.08 \%$ \\
\hline Betaproteobacteria & $42.99 \%$ \\
\hline Deltaproteobacteria & $6.41 \%$ \\
\hline Epsilonproteobacteria & $0.36 \%$ \\
\hline Gammaproteobacteria & $25.48 \%$ \\
\hline \multicolumn{2}{|c|}{ Unclassified Proteobacteria $0.12 \%$} \\
\hline Spirochaetes & $0.08 \%$ \\
\hline Verrucomicrobia & $0.88 \%$ \\
\hline$B R C 1$ & $0.04 \%$ \\
\hline Cyanobacteria & $0.52 \%$ \\
\hline$O D 1$ & $0.04 \%$ \\
\hline OPIO & $0.04 \%$ \\
\hline TM7 & $0.12 \%$ \\
\hline WS3 & $0.04 \%$ \\
\hline Unclassified Bacteria & $1.60 \%$ \\
\hline
\end{tabular}

MIN $\square$ MAX

Fig. 4. Distribution of bacterial groups in sediment cores taken from 5 sites (A to E) on the Yellow River. See Fig. 3 legend for further explanation of site labels. The colors of the squares indicate the relative abundance of the corresponding group at each site, ranging from red (high) to white (low). Numbers following the taxa names indicate their relative abundances in the total 
river sediment environments and generally important contributors to biogeochemical processes (Barns et al., 1999, Spring et al. 2000, Li et al. 2008). For example, Feng et al. (2009) reported that Proteobacteria is the most abundant phylum, followed by Firmicutes, Bacteroidetes, and Actinobacteria in water and sediments of the Changjiang estuary and coastal area of the East China Sea.

When the sequences were assigned to the taxonomic rank of order (see Fig. S1 in the Supplement), Burkholderiales (666 sequences, $26.7 \%$ ), Xanthomonadales $(374,15.0 \%)$, Pseudomonadales (194, 7.8\%), Rhodocyclales (131, 5.2\%), and Flavobacteriales $(103,4.1 \%)$ were predominant in sediment samples. The constructed phylogenetic tree showed that the most abundant genera were affiliated with Nevskia (201 sequences, $8.1 \%)$, Pseudomonas (151, 6.0\%), Hydrogenophaga (134, 5.4\%), Thiobacillus (88, $3.5 \%)$, Rhodoferax (86, $3.4 \%)$, and unclassified Betaproteobacteria (84, 3.4\%) (Fig. 5).

For the most abundant sequences affiliated with Proteobacteria, its subphyla Betaproteobacteria $(43.0 \%)$ and Gammaproteobacteria (25.5\%) were markedly more abundant than Alphaproteobacteria $(3.08 \%)$, Epsilonproteobacteria $(0.36 \%)$, and unclassified Proteobacteria $(0.12 \%)$ in the Yellow River sediment. Betaproteobacteria has been frequently found with a high relative abundance in freshwater sedi- ments and waters (Zwart et al. 2002, Wilms et al. 2006, Nelson et al. 2007). In contrast, marine ecosystems usually contain very few Betaproteobacteria (Rappé et al. 2000). In soil, the proportion of Betaproteobacteria has been found to be much lower than that of Alphaproteobacteria, and especially lower than that of members of the Fibrobacteres/Acidobacteria group (Chow et al. 2002, Zhou et al. 2003). In addition, the representatives of Gammaproteobacteria accounted for a relatively high percentage of the bacterial community composition of the river sediment in this study, which is consistent with results obtained by Enya et al. (2007). Although Alphaproteobacteria is considered characteristic of marine environments (Acinas et al. 1999), this subphylum was also found in the Yellow River sediment.

The Yellow River, with its high sediment load, has suffered from low water yields and heavy water pollution ( $\mathrm{Li}$ et al. 2006, Xia et al. 2009), which may affect the structure of bacterial communities. Members of Firmicutes, which are versatile in degrading macromolecules (Vieira et al. 2008), accounted for $0.28 \%$ of bacteria in the sediments of the Yellow River. Additionally, the high water turbidity, low water transparency and low light transmission rate in the Yellow River could affect the growth of photosynthetic bacteria in the sediment. As expected, Cyanobacteria, Chloroflexi, and Chlorobi, which are repre-

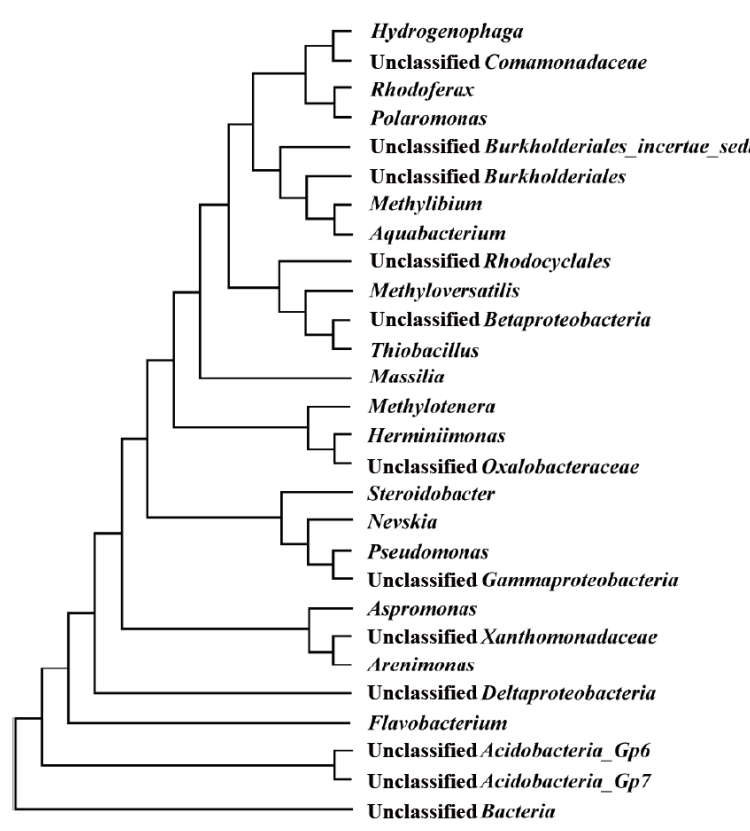

Fig. 5. Phylogenetic tree and taxonomic assignment of the dominant genera (relative abundance $>1.0 \%$ ) among $249616 \mathrm{~S}$ rRNA gene sequences in 25 clone libraries constructed from sediment cores taken from 5 sites (A to E) on the Yellow River. See Fig. 3 legend for further explanation of site labels. The colors of the squares indicate the relative abundance of the corresponding genus at each site, ranging from red (high) to white (low). Relative abundances in the total sequences (\%) are shown 
sentatives of the photosynthetic bacteria, were present with low frequencies in the Yellow River sediment.

\section{Spatial variation among bacterial communities in the sediments of 5 sampling sites}

According to the total bacterial communities in each sediment core (i.e. $0-25 \mathrm{~cm}$ depth), the numbers of bacterial clone sequences at the sampling sites $A$, B, C, D, and E were 553, 491, 464, 500, and 488, respectively; and the numbers of OTUs were 375, 202, 285, 366, and 305, respectively. The Shannon indices at the 5 sites were 5.56, 4.09, 5.19, 5.57, and 4.13 , respectively. Thus, the bacterial diversity in the sediment varied at the 5 sampling sites, but no trend existed along the Yellow River.

Bacterial community structures among the 5 sampling sites are compared at Fig. 6. Although clones belonging to phyla Proteobacteria, Bacteroidetes, Acidobacteria, Planctomycetes, and Verrucomicrobia were present at all sampling sites, their relative abundances and main subphylum compositions differed among the sites. The relative abundances of Proteobacteria as the predominant phylum at the 5 sites A to E were $76.1,94.7,61.9,75.8$, and $82.2 \%$, respectively. For the subphyla of Proteobacteria, the relative abundances of Betaproteobacteria at the 5 sites were $51.4,34.1,35.4,39.0$, and 52.8\%, respectively, and those of Gammaproteobacteria were 15.9, 53.7, 15.1, 26.8 , and $16.8 \%$, respectively. Betaproteobacteria was predominant at sites A, C, D, and E, whereas Gammaproteobacteria was predominant at site $\mathrm{B}$. The second main phylum at sites A, B, C, and E was Bacteriodetes, whose relative abundance was $8.9,1.7,24.1$, and $6.3 \%$, respectively, while the second main phylum at site D was Acidobacteria $(10.2 \%)$. In addition, some phyla were only found at some of the 5 sites. For example, Actinobacteria, Firmicutes, and Gemmatimonadetes were found at sites A, C, D, and $\mathrm{E}_{\mathrm{i}}$ Nitrospira was found at sites $A_{1}, B$, and $C_{i}$ Chloroflexi was found at sites A, C and D; Cyanobacteria was found at sites A, D and $E_{\text {; }}$ Spirochaetes was found at sites A and D; Chlorobi was found at sites C and D. $B R C 1, O P 10$, and WS3 were only found at site $\mathrm{A}_{i}$ Deferribacteries, Fusobacteria, Lentisphaerae, and OD1 were only found at site D; TM7 only appeared at site E. These results indicated clear dif-

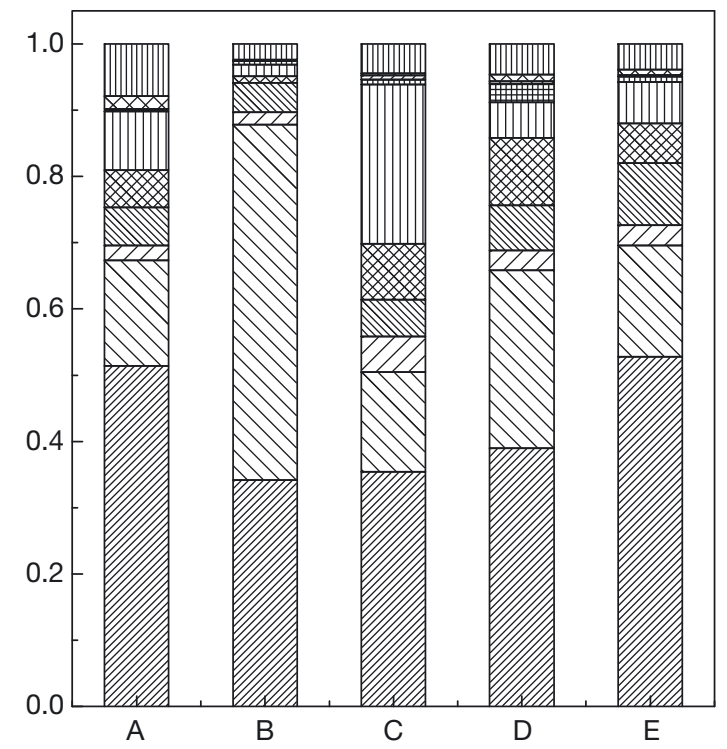

mIn⿴⿱冂一⿰丨丨⿴囗十ा Others

$\square$ Verrucomicrobia ZIJ Firmicutes Planctomycetes एس山ा Bacteroidetes Acidobacteria Deltaproteobacteria $Z$ Alphaproteobacteria $\triangle \backslash$ Gammaproteobacteria 10 Betaproteobacteria

Fig. 6. Bacterial community compositions at phylum and subphylum levels in sediments (0$25 \mathrm{~cm}$ depth) at $5 \mathrm{sam}$ pling sites (A to E) on the Yellow River 
tively; the relative abundances of Gammaproteobacteria in the 5 layers were 36, 23, 29, 35, and $11 \%$, respectively. Bacteroidetes and Acidobacteria were also an important part of bacterial community compositions in the 5 layers. The relative abundances of Bacteroidetes were 2, 4, 8, 4, and $9 \%$, respectively. The relative abundances of Acidobacteria were 5, 9, 13,6 , and $18 \%$, respectively. In addition, some phyla were only found in some of the 5 layers. For example, Verrucomicrobia was found in D1, D3, and D5; Firmicutes was found in D1, D3, and D5; Chlorobi was found in D2 and D4; Actinobacteria was only found in D3; Cyanobacteria, Deferribacteres, Fusobacteria, and $O D 1$ were only found in D5; unclassified Proteobacteria and Spirochaetes were only found in D1.

Thus, although the bacterial communities varied among the sediment layers for each site, there was no significant trend with depth in the Yellow River sediment. This result was inconsistent with previous studies of other freshwater sediments. For instance, Röske et al. (2012) observed that the predominant subphylum Betaproteobacteria decreased with sediment depth, but the second largest subphylum Deltaproteobacteria increased with sediment depth in the Saidenbach Reservoir (Saxony, Germany). Ye et al. (2009) reported that the bacterial community composition appeared to be relatively homogeneous in 6 sediment layer samples (from 0 to $30 \mathrm{~cm}$ ) in Lake Taihu. Huang et al. (2011) indicated that the total bacterial abundance and bacterial activity decreased with depth in sediment samples collected from the Pearl River, and the vertical distributions of bacterial characteristics were affected by depth-related environmental factors. However, Beier et al. (2008) studied the bacterial communities in 2 sediment cores from different sites along a stream in central Germany and found that while one core exhibited clear stratification of the communities across depth, another core, which was exposed to more turbulent conditions, did not reveal distinct stratification. Böer et al. (2009) reported that the bacterial community structure in a shallow subtidal sand flat in the North Frisian Wadden Sea had a clear vertical variation, with higher OTU numbers at 10 to $15 \mathrm{~cm}$ depth than in the top $10 \mathrm{~cm}$, probably because of the decreasing disturbance by hydrodynamic forces with sediment depth.

\section{Relationships between bacterial communities and environmental variables}

The RDA results (Fig. 7) based on species assemblage data (of species with relative abundance
$>0.2 \%$ ) and environmental variables, including nutrient concentrations, depth, water content, TOC/TN, $\mathrm{pH}$ and ORP, showed that the sediment characteristics had an important influence on bacterial community distributions. Axis 1 explained $21.3 \%$ of the total variation of the hybridization data, Axes 1 and 2 explained $32.0 \%$, and all 4 axes explained $42.9 \%$. Species-environment correlations were high, especially for Axis 1 and 2 (0.839 and 0.941 respectively), indicating a strong relationship between species and environmental variables. In addition, as shown in Fig. 7 , the 5 sediment layer samples of each sediment

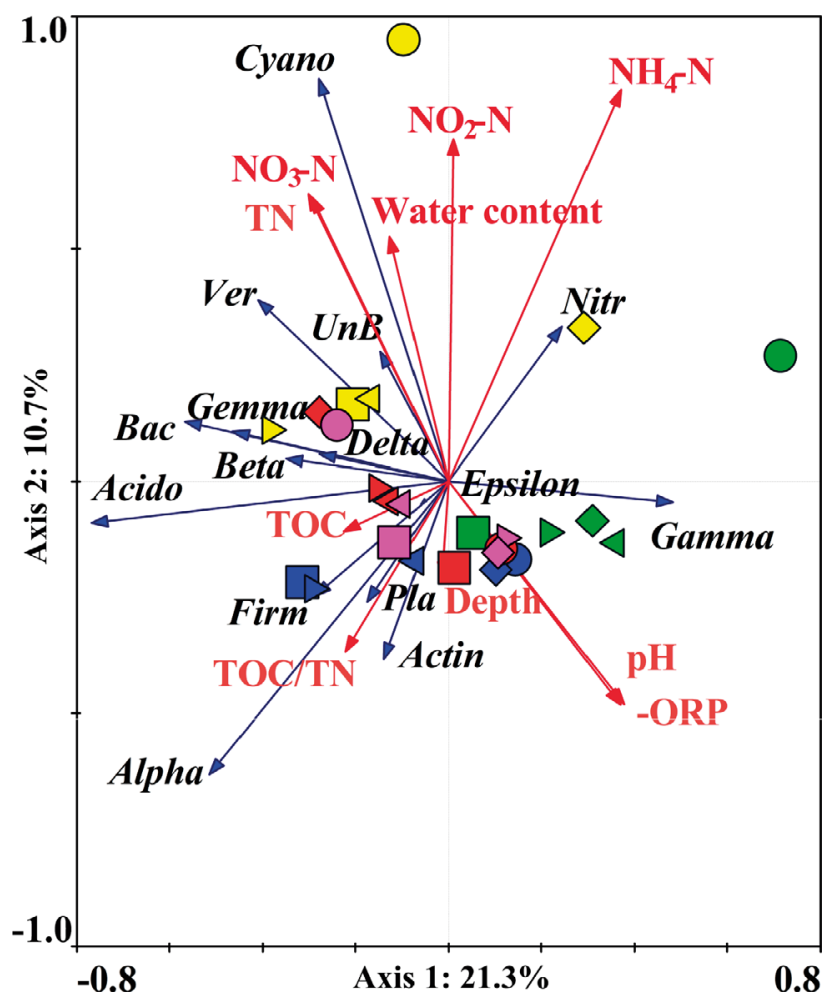

Fig. 7. Redundancy analysis of species assemblage data (based on species comprising $>0.2 \%$ of the total 2496 clones) (blue lines) and environmental variables (red lines) in core sediment samples taken from 5 sites on the Yellow River: A (yellow), B (green), C (blue), D (red), and E (purple) (see Fig. 1 for site locations). At each site, samples were

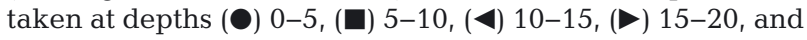
( ) 20-25 cm depth. Acido: Acidobacteria; Actin: Actinobacteria; Bac: Bacteroidetes; Firm: Firmicutes; Gemma: Gemmatimonadetes; Pla: Planctomycetes; Nitr: Nitrospira; Alpha: Alphaproteobacteria; Beta: Betaproteobacteria; Cyano: Cyanobacteria; Ver: Verrucomicrobia; Gamma: Gammaproteobacteria; Epsilon: Epsilonproteobacteria; Delta: Deltaproteobacteria; UnB: unclassified Bacteria. See Fig. 2 legend for abbreviations of environmental variables. The lengths of the arrows indicate how much variance was explained by that the corresponding variable. The angles between arrows indicate correlations between individual environmental variables 
core and the samples of each sediment layer from the 5 sampling sites did not cluster together, providing further evidence of the spatial and vertical variations among bacterial community compositions in the Yellow River sediment.

As shown in Fig. 7, there was a significant positive correlation between Nitrospira and $\mathrm{NH}_{4}-\mathrm{N}$ and $\mathrm{NO}_{3}-\mathrm{N}$ concentrations. These nutrients act as its growth substrate, suggesting that nitrification might be an important process in the Yellow River sediment. The abundance of Betaproteobacteria, the dominant subphylum in the sediment samples, was closely related with nutrient concentrations, including TOC, $\mathrm{NO}_{2}-\mathrm{N}, \mathrm{NO}_{3}-\mathrm{N}$, and $\mathrm{TN}$. This can be explained by the fact that Betaproteobacteria consists of groups of aerobic or facultative bacteria (Freitag et al. 2006), many of which perform functions of nitrification and denitrification. In addition, Cyanobacteria correlated positively with $\mathrm{TN}, \mathrm{NO}_{2}-\mathrm{N}$, $\mathrm{NO}_{3}-\mathrm{N}$, and ORP, whereas it correlated negatively with $\mathrm{pH}$. Firmicutes correlated positively with TOC, and negatively with $\mathrm{NH}_{4}-\mathrm{N}$.

Furthermore, Monte Carlo variable tests (Table 3) indicated that $\mathrm{NH}_{4}-\mathrm{N}$ and $\mathrm{NO}_{3}-\mathrm{N}$ exhibited significant influences on the bacterial assemblages in the Yellow River sediment $(\mathrm{p}<0.05)$. This result was consistent with those of other studies (Chunleuchanon et al. 2003, Huang et al. 2011). However, these inorganic nitrogen compounds are likely not directly responsible for the patterns of bacterial diversity. The influence of inorganic nitrogen compounds on bacterial community composition is stronger when combined with other factors, such as organic nitrogen and carbon compounds and waste water inputs (D'Hondt et al. 2004, Lozupone \& Knight 2007). In the Yellow River, waste water input is an important pol-

Table 3. Monte Carlo permutation testing results between bacterial community composition and environmental variables. ORP: oxidation-reduction potential; TOC: total organic carbon; TN: total nitrogen; $\mathrm{NH}_{4}-\mathrm{N}$ : ammonium nitrogen; $\mathrm{NO}_{2}-\mathrm{N}$ : nitrite nitrogen, $\mathrm{NO}_{3}-\mathrm{N}$ : nitrate nitrogen. ${ }^{*} \mathrm{p}<0.05$

\begin{tabular}{|lcc|}
\hline Variable & $F$ & $\mathrm{p}$ \\
\hline $\mathrm{NH}_{4}-\mathrm{N}$ & 2.86 & $0.014^{*}$ \\
$\mathrm{NO}_{3}-\mathrm{N}$ & 1.92 & $0.04^{*}$ \\
$\mathrm{TN}$ & 1.96 & 0.052 \\
$\mathrm{pH}$ & 1.77 & 0.062 \\
$\mathrm{NO}-\mathrm{N}$ & 1.95 & 0.064 \\
$\mathrm{ORP}$ & 1.86 & 0.064 \\
Water content & 1.48 & 0.138 \\
Depth & 1.12 & 0.308 \\
TOC/TN & 0.95 & 0.414 \\
TOC & 0.90 & 0.526 \\
\hline
\end{tabular}

lution source that is high in inorganic nitrogen and carbon compounds (Xia et al. 2002). Therefore, the relationship between inorganic nitrogen compounds and bacterial diversity is indirect; the phenomenon could be caused by a wide range of environmental factors.

As shown in Table 3 and Fig. 7, depth did not have a significant effect on the bacterial communities in the sediment samples ( $p>0.05)$. This was consistent with the aforementioned results that bacterial diversities and community compositions in each sediment core had no significant trend with depth. The reason might be that variation of hydrodynamic conditions resulted in high-frequency resuspension and deposition of sediment in the Yellow River. Water-sediment regulation at the Xiaolangdi Reservoir results in resuspension and deposition of sediment in the middle and lower reaches of the Yellow River, and the mixing of different layer sediments. This could explain why environmental parameters did not show a significant trend with depth (Fig. 2) and, further, why the bacterial communities of the sediment-core samples showed vertical variations but exhibited no significant trend with depth.

Acknowledgements. The study was supported by the Major State Basic Research Development Program (2010 CB951104), National Science Foundation for Distinguished Young Scholars (51325902), National Science Foundation for Innovative Research Group (51121003), and National Science Foundation of China (51279010).

\section{LITERATURE CITED}

Acinas SG, Antón J, Rodríguez-Valera F (1999) Diversity of free-living and attached bacteria in offshore western Mediterranean waters as depicted by analysis of genes encoding 16S rRNA. Appl Environ Microbiol 65:514-522

Barns SM, Takala SL, Kuske CR (1999) Wide distribution and diversity of members of the bacterial kindom Acidobacterium in the environment. Appl Environ Microbiol 65:1731-1737

> Beier S, Witzel KP, Marxsen J (2008) Bacterial community composition in central European running waters examined by temperature gradient gel electrophoresis and sequence analysis of 16S rRNA genes. Appl Environ Microbiol 74:188-199

> Böer SI, Hedtkamp SIC, van Beusekom JEE, Fuhrman JA, Boetius A, Ramette A (2009) Time- and sediment depthrelated variations in bacterial diversity and community structure in subtidal sands. ISME J 3:780-791

Bushaw-Newton KL, Ewers EC, Velinsky DJ, Ashley JT, MacAvoy SE (2012) Bacterial community profiles from sediments of the Anacostia River using metabolic and molecular analyses. Environ Sci Pollut R 19:1271-1279

> Chow ML, Radomski CC, McDermott JM, Davies J, Axelrood PE (2002) Molecular characterization of bacterial diversity in Lodgepole pine (Pinus contorta) rhizosphere 
soils from British Columbia forest soils differing in disturbance and geographic source. FEMS Microbiol Ecol 42: 347-357

Chunleuchanon S, Sooksawang A, Teaumroong N, Boonkerd N (2003) Diversity of nitrogen-fixing cyanobacteria under various ecosystems of Thailand: population dynamics as affected by environmental factors. World J Microb Biot 19:167-173

D'Hondt S, Jørgensen BB, Miller DJ, Batzke A and others (2004) Distributions of microbial activities in deep subseafloor sediments. Science 306:2216-2221

> Doong RA, Lin YT (2004) Characterization and distribution of polycyclic aromatic hydrocarbon contaminations in surface sediment and water from Gao-ping River, Taiwan. Water Res 38:1733-1744

Edlund A, Soule T, Sjöling S, Jansson JK (2006) Microbial community structure in polluted Baltic Sea sediments. Environ Microbiol 8:223-232

Enya J, Shinohara H, Yoshida S, Tsukiboshi T, Negishi H, Suyama K, Tsushima S (2007) Culturable leaf-associated bacteria on tomato plants and their potential as biological control agents. Microb Ecol 53:524-536

> Feng BW, Li XR, Wang JH, Hu ZY, Meng H, Xiang LY, Quan ZX (2009) Bacterial diversity of water and sediment in the Changjiang estuary and coastal area of the East China Sea. FEMS Microbiol Ecol 70:236-248

> Freitag TE, Chang L, Prosser JI (2006) Changes in the community structure and activity of betaproteobacterial ammonia-oxidizing sediment bacteria along a freshwater-marine gradient. Environ Microbiol 8:684-696

García-Moyano A, González-Toril E, Aguilera Á, Amils R (2012) Comparative microbial ecology study of the sediments and the water column of the Río Tinto, an extreme acidic environment. FEMS Microbiol Ecol 81:303-314

Garcia-Ruiz R, Pattinson S, Whitton B (1998) Denitrification in river sediments: relationship between process rate and properties of water and sediment. Freshw Biol 39:467-476

> Huang S, Chen C, Wu YY, Wu QH, Zhang RD (2011) Characterization of depth-related bacterial communities and their relationships with the environmental factors in the river sediments. World J Microb Biot 27:2655-2664

Jongman RH, Ter Braak CJ, van Tongeren OF (1995) Data analysis in community and landscape ecology. Cambridge University Press, Cambridge

> Junier P, Witzel KP, Hadas O (2007) Genetic diversity of cyanobacterial communities in Lake Kinneret (Israel) using 16S rRNA gene, psbA and ntcA sequence analyses. Aquat Microb Ecol 49:233-241

Kondo R, Butani J (2007) Comparison of the diversity of sulfate-reducing bacterial communities in the water column and the surface sediments of a Japanese meromictic lake. Limnology 8:131-141

Lane D (1991) 16S/23S rRNA sequencing. In: Stackebrandt E, Goodfellow M (eds) Nucleic acid techniques in bacterial systematics. John Wiley \& Sons, Chichester, p 115-175

> Li G, Xia XH, Yang ZF, Wang R, Voulvoulis N (2006) Distribution and sources of polycyclic aromatic hydrocarbons in the middle and lower reaches of the Yellow River, China. Environ Pollut 144:985-993

> Li D, Yang M, Li ZL, Qi R, He JZ, Liu HJ (2008) Change of bacterial communities in sediments along Songhua River in Northeastern China after a nitrobenzene pollution event. FEMS Microbiol Ecol 65:494-503

Liu SD, Xia XH, Zhai YW, Wang R, Liu T, Zhang SW (2011) Black carbon $(\mathrm{BC})$ in urban and surrounding rural soils of
Beijing, China: spatial distribution and relationship with polycyclic aromatic hydrocarbons (PAHs). Chemosphere 82:223-228

Liu T, Xia XH, Liu SD, Mou XL, Qiu YW (2013) Acceleration of denitrification in turbid rivers due to denitrification occurring on suspended sediment in oxic waters. Environ Sci Technol 47:4053-4061

Lozupone CA, Knight R (2007) Global patterns in bacterial diversity. Proc Natl Acad Sci USA 104:11436-11440

> Marxsen J, Zoppini A, Wilczek S (2010) Microbial communities in streambed sediments recovering from desiccation. FEMS Microbiol Ecol 71:374-386

Nealson KH (1997) Sediment bacteria: who's there, what are they doing, and what's new? Annu Rev Earth Planet Sci 25:403-434

Nelson DM, Ohene-Adjei S, Hu FS, Cann IKO, Mackie RI (2007) Bacterial diversity and distribution in the Holocene sediments of a northern temperate lake. Microb Ecol 54:252-263

Rappé MS, Vergin K, Giovannoni SJ (2000) Phylogenetic comparisons of a coastal bacterioplankton community with its counterparts in open ocean and freshwater systems. FEMS Microbiol Ecol 33:219-232

Röske K, Sachse R, Scheerer C, Röske I (2012) Microbial diversity and composition of the sediment in the drinking water reservoir Saidenbach (Saxonia, Germany). Syst Appl Microbiol 35:35-44

Salles JF, Van Veen JA, Van Elsas JD (2004) Multivariate analyses of Burkholderia species in soil: effect of crop and land use history. Appl Environ Microbiol 70:4012-4020

Schloss PD, Westcott SL, Ryabin T, Hall JR and others (2009) Introducing mothur: open-source, platform-independent, community-supported software for describing and comparing microbial communities. Appl Environ Microbiol 75:7537-7541

Song H, Li Z, Du B, Wang G, Ding Y (2012) Bacterial communities in sediments of the shallow Lake Dongping in China. J Appl Microbiol 112:79-89

Spring S, Schulze R, Overmann J, Schleifer KH (2000) Identification and characterization of ecologically significant prokaryotes in the sediment of freshwater lakes: molecular and cultivation studies. FEMS Microbiol Rev 24: 573-590

Tamaki H, Sekiguchi Y, Hanada S, Nakamura K, Nomura N, Matsumura M, Kamagata Y (2005) Comparative analysis of bacterial diversity in freshwater sediment of a shallow eutrophic lake by molecular and improved cultivationbased techniques. Appl Environ Microbiol 71:2162-2169

Van Der Zaan B, Smidt H, De Vos WM, Rijnaarts H, Gerritse J (2010) Stability of the total and functional microbial communities in river sediment mesocosms exposed to anthropogenic disturbances. FEMS Microbiol Ecol 74: $72-82$

Vieira RP, Gonzalez AM, Cardoso AM, Oliveira DN and others (2008) Relationships between bacterial diversity and environmental variables in a tropical marine environment, Rio de Janeiro. Environ Microbiol 10:189-199

> Wang Q, Garrity GM, Tiedje JM, Cole JR (2007) Naive Bayesian classifier for rapid assignment of rRNA sequences into the new bacterial taxonomy. Appl Environ Microbiol 73:5261-5267

Wang HY, Shen ZY, Niu JF, He Y, Hong Q, Wang Y (2010) Functional bacteria as potential indicators of water quality in Three Gorges Reservoir, China. Environ Monit Assess 163:607-617 
Whitman WB, Coleman DC, Wiebe WJ (1998) Prokaryotes: the unseen majority. Proc Natl Acad Sci USA 95:6578-6583

Wilms R, Sass H, Köpke B, Köster J, Cypionka H, Engelen B (2006) Specific bacterial, archaeal, and eukaryotic communities in tidal-flat sediments along a vertical profile of several meters. Appl Environ Microbiol 72:2756-2764

Xia XH, Zhou JS, Yang ZF (2002) Nitrogen contamination in the Yellow River basin of China. J Environ Qual 31: 917-925

Xia XH, Yu H, Yang ZF, Huang GH (2006) Biodegradation of polycyclic aromatic hydrocarbons in the natural waters of the Yellow River: effects of high sediment content on biodegradation. Chemosphere 65:457-466

Xia XH, Yang ZF, Zhang XQ (2009) Effect of suspendedsediment concentration on nitrification in river water: importance of suspended sediment-water interface. Environ Sci Technol 43:3681-3687

Yang T, Zhang Q, Chen YD, Tao X, Xu CY, Chen X (2008) A spatial assessment of hydrologic alteration caused by dam construction in the middle and lower Yellow River, China. Hydrol Processes 22:3829-3843

Ye W, Liu X, Lin S, Tan J, Pan J, Li D, Yang H (2009) The ver-

Editorial responsibility: Hans-Georg Hoppe, Kiel, Germany tical distribution of bacterial and archaeal communities in the water and sediment of Lake Taihu. FEMS Microbiol Ecol 70:263-276

YRCC (Yellow River Conservancy Commission) (2010) Yellow River sediment bulletin. YRCC, Zhengzhou (in Chinese)

Zeglin LH, Dahm CN, Barrett JE, Gooseff MN, Fitpatrick SK, Takacs-Vesbach CD (2011) Bacterial community structure along moisture gradients in the parafluvial sediments of two ephemeral desert streams. Microb Ecol 61: 543-556

Zehr JP, Ward BB (2002) Nitrogen cycling in the ocean: new perspectives on processes and paradigms. Appl Environ Microbiol 68:1015-1024

> Zhou J, Xia B, Huang H, Treves DS and others (2003) Bacterial phylogenetic diversity and a novel candidate division of two humid region, sandy surface soils. Soil Biol Biochem 35:915-924

Zwart G, Crump BC, Kamst-van Agterveld MP, Hagen F, Han SK (2002) Typical freshwater bacteria: an analysis of available 16S rRNA gene sequences from plankton of lakes and rivers. Aquat Microb Ecol 28:141-155

Submitted: April 22, 2013; Accepted: September 13, 2013 Proofs received from author(s): November 13, 2013 